\title{
セットバックのある建築物の地震応答特性 EARTHQUAKE RESPONSE CHARACTERISTICS OF BUILDINGS WITH SETBACK
}

\author{
倉本 洋*, 佐 藤昌 紀** \\ Hiroshi KURAMOTO and Masaki SATO
}

\begin{abstract}
Applying an earthquake response evaluation method of buildings proposed by the authors, which uses the equivalent SDOF system responses and the higher mode responses obtained from both the time history earthquake response analysis and the modal adaptive pushover (MAP) analysis, the earthquake response characteristics of RC buildings with setback were investigated. Analyzed were four twelve-story RC buildings with different setback layouts. The results indicate that translation responses are more dominant than torsional responses for buildings with setback in the upper story, while torsional responses tend to be prominent for buildings with setback in the lower story. It is also clarified that torsional responses are extremely increased at a story right under the setback story, and the torsional responses include a lot of higher mode components.
\end{abstract}

Keywords : Buildings with setback, Earthquake response characteristics, Equivalent SDOF system, Higher mode response, Mode-adaptive pushover analysis, Earthquake response analysis セットバック建築物, 地震応答特性, 等価 1 自由度系, 高次モード応答, MAP 解析, 地震応答解析

\section{1.はじめに}

著者等は、限界耐力計算による耐震性能評価法の改善を目的とし た研究の一環として、㨭孔振動が卓越する偏心建築物の地震応答特 性の解明と等価 1 自由度系への縮約法および高次モード応答の評価

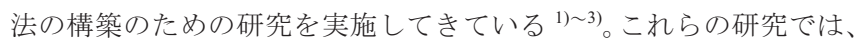
各層において平面形状が同一で、重心位置が同一鉛直線上にある偏 心建築物を対象としてきた。これに対して、各層で質量が偏在して いる建築物や層によって平面形状が異なる建築物でも、各層の重心 位置が同一鋁直線上にないことに起因した立面的な偏心によって㨭 れ振動が生じる。そのような建築物のひとつにセットバックしてい る建築物（以下、セットバック建築物と呼称）がある。セットバッ ク建築物ではセットバックしていない層（以下、基準層と呼称）と セットバックしている層（以下、セットバック層と呼称）とで重心 位置が異なるために捩れ振動が生じる。セットバック建築物を対象 とした据れ振動に関寸る研究については、古くは志賀の研究 ${ }^{4)}$ があ

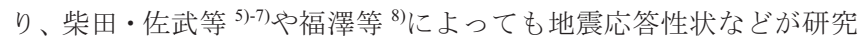
されているが、総じて少ないのが現状である。

そこで本研究では、筆者等が展開している等価 1 自由度系応答と 高次モード応答による建築物の地震応答評価法をセットバック建築 物に適用し、その地震応答特性を検討寸ることを目的としている。 本論では、セットバック形状の異なる 4 タイプの建築物を対象とし て、時刻歴地震応答解析と静的非線形荷重増分解析を実施し、それ らの結果に基づいて縮約された等価 1 自由度系から 1 次モード応答
特性を考察するとともに、建築物全体および各構面の地震応答性状 に及ぼす高次モード応答の影響を検討する。

\section{2. 対象建築物および解析概要}

解析対象とした建築物は、図 1 に示すように、 $x$ 方向構面が片側 にセットバックしている 12 層鉄筋コンクリート $(\mathrm{RC})$ 造建築物で、 セットバック層数およびセットバック層の平面形状が異なる 4 モデ ル（モデル $\mathrm{A} \sim \mathrm{D} ）$ である。架構形式は $x$ 方向が 1 スパンの連層耐 震壁構造で $y$ 方向が最大 4 スパンの純ラーメン構造である。表 1 に 解析モデルの概要を、表 2 に $x$ 方向の $1 \sim 3$ 次の固有周期、等価質量 および等価質量比をそれぞれ示す。また、図 2 には各解析モデルの モード図（1３次）を示している。

各解析モデルは、(軸力の影響を無視すると）層ごとに偏心しない ように部材が配置されているが、建築物全体としてはセットバック 層の影響で 1 軸偏心を生じるものとなっている。柱、梁および耐震 壁の断面詳細を表 3 5 に示す。モデル A は最上層の 1 構面のみが セットバックしており、モデル B は最上層の 3 構面がセットバック したモデルとなっている。モデル C は 7 層から最上層まで 1 構面が セットバックしたモデルである。また、モデル D は 7 層から最上層 までが 2 層ごとに 1 構面ずつセットバックしたものである。なお、 各解析モデルは、 $x$ 方向では連層耐震壁が 1 階壁脚で曲げ降伏先行 型となるように、 $y$ 方向では梁曲げ降伏先行型となるようにそれぞ れ設計されている。また、モデル $\mathrm{A} 、 \mathrm{~B} 、 \mathrm{C}$ および $\mathrm{D}$ の $x$ 方向の心゙
* 大阪大学大学院工学研究科地球総合工学専攻

教授・博士 (工学)

** 和田建築技術研究所 修士 (工学)

（元 豊橋技術科学大学大学院 大学院生
Prof., Department of Architectural Engineering, Graduate School of Engineering, Osaka University, Dr. Eng.

Wada Structural Engineer Consultant, M. Eng.

(Former Graduate Student, Toyohashi University of Technology) 

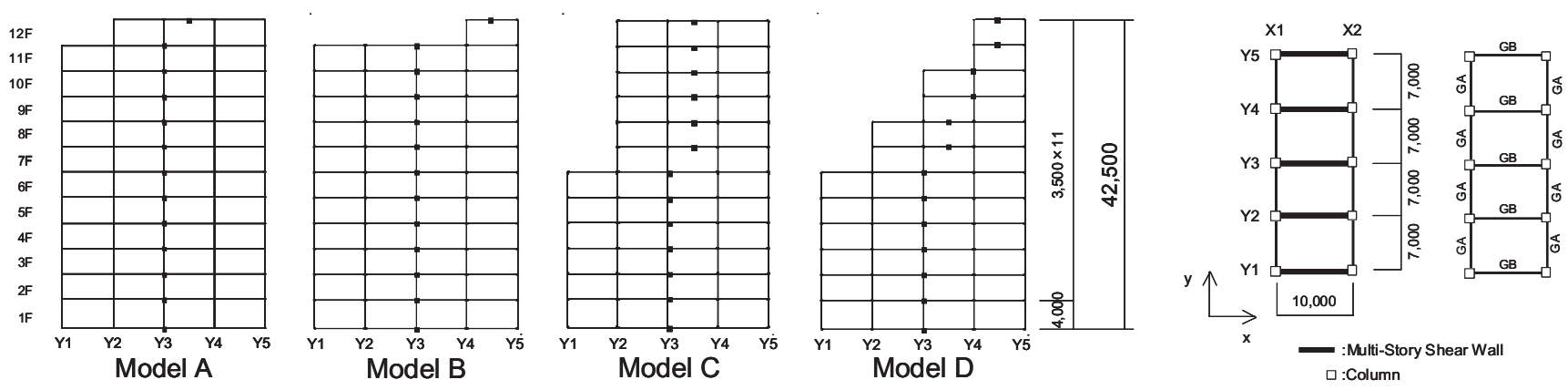

図 1 解析モデル

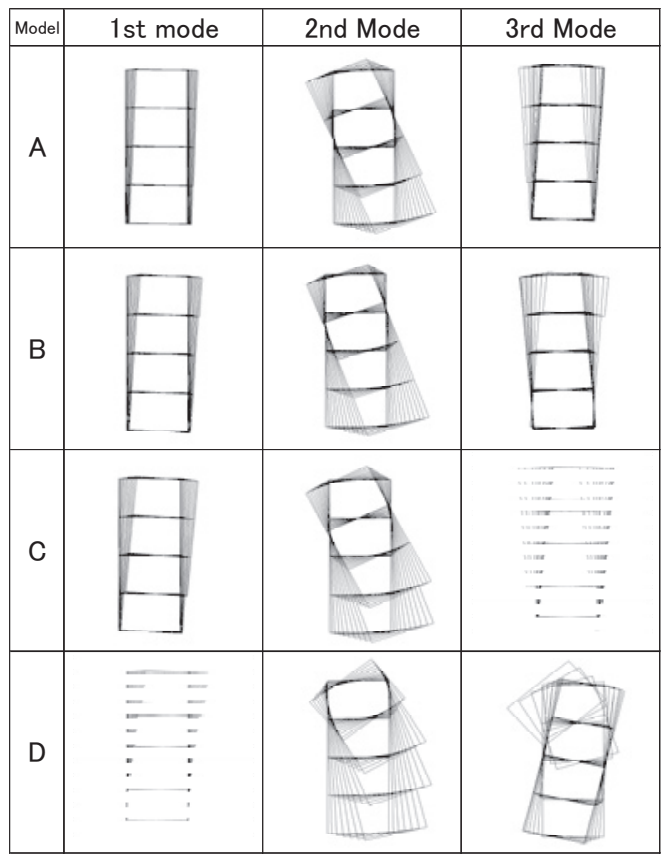

図 2 モード図

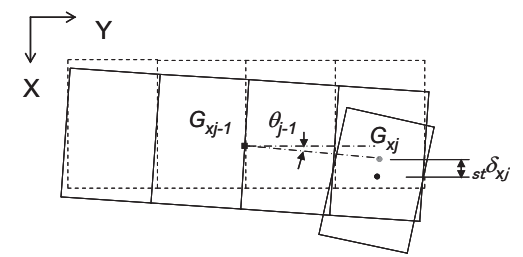

図 3 重心位置の取扱い

表 1 解析モデルの概要

\begin{tabular}{|c|c|c|c|c|c|c|c|}
\hline \multirow{2}{*}{ モデル } & \multirow[t]{2}{*}{ 層 } & \multirow{2}{*}{$\begin{array}{l}\text { 質量 } \\
\text { [ton] }\end{array}$} & \multicolumn{2}{|c|}{$\begin{array}{c}\begin{array}{c}\text { 重心位置*1 } \\
{[\mathrm{cm}]}\end{array} \\
\end{array}$} & \multirow{2}{*}{$\begin{array}{c}\text { 回転半洤 } \\
{[\mathrm{cm}]}\end{array}$} & \multicolumn{2}{|c|}{ 弾力半径比 } \\
\hline & & & & & & & \\
\hline \multirow[b]{2}{*}{ A } & 1層 & 348 & 500 & 1400 & 1028 & \begin{tabular}{|l|}
0.98 \\
\end{tabular} & 2.68 \\
\hline & セットバック(12)層 & 224 & 500 & 1750 & 856 & \begin{tabular}{|l|}
1.32 \\
\end{tabular} & 0.82 \\
\hline \multirow{2}{*}{ B } & 1層 & 348 & 500 & 1400 & 1028 & 0.96 & 2.63 \\
\hline & セットバック(12)層 & 83 & 500 & 2450 & 610 & 1.37 & 0.90 \\
\hline \multirow[t]{2}{*}{ C } & 1層 & 348 & 500 & 1400 & 1028 & 0.95 & 2.53 \\
\hline & セットバック(7)層 & $\frac{256}{340}$ & $\frac{500}{500}$ & 1750 & $\frac{863}{1020}$ & \begin{tabular}{|l}
1.00 \\
100
\end{tabular} & $\frac{1.39}{282}$ \\
\hline \multirow{4}{*}{ D } & 1層 & 348 & 500 & 1400 & 1028 & \begin{tabular}{|l|l|}
1.00 \\
0.9 \\
\end{tabular} & 2.82 \\
\hline & セットバック(7)層 & 256 & 500 & 1750 & 863 & \begin{tabular}{|l|l|}
0.88 \\
\end{tabular} & 1.07 \\
\hline & セッドッ゙ク(9)層 & 172 & 500 & 2100 & 721 & \begin{tabular}{|l|}
0.96 \\
\end{tabular} & 1.23 \\
\hline & セットバック(11)層 & 95 & 500 & \begin{tabular}{|l|l|}
2450 \\
\end{tabular} & 610 & \begin{tabular}{|l|}
0.99 \\
\end{tabular} & 1.00 \\
\hline
\end{tabular}

表 2 等価質量および質量比

\begin{tabular}{|c|c|c|c|c|}
\hline \multicolumn{2}{|c|}{ モデル } & $\begin{array}{c}\text { 固有周期 } \\
{[\mathrm{sec}]}\end{array}$ & $\begin{array}{c}\text { 等価質量 } \\
\text { [ton] }\end{array}$ & 等価質量比 \\
\hline \multirow{3}{*}{ A } & 1次 & $\begin{array}{l}\text { Lsec] } \\
0.431\end{array}$ & 2435 & $\overline{0.62}$ \\
\hline & 2次 & 0.385 & 226 & 0.06 \\
\hline & 3次 & 0.113 & 830 & 0.21 \\
\hline \multirow{3}{*}{ B } & 1次 & 0.408 & 2013 & 0.53 \\
\hline & 2次 & 0.371 & 559 & 0.15 \\
\hline & 3次 & 0.11 & 526 & 0.14 \\
\hline & 1次 & 0.424 & 1860 & 0.53 \\
\hline \multirow[t]{2}{*}{ C } & 2次 & 0.319 & 368 & 0.10 \\
\hline & 3次 & 0.1 & 353 & 0.10 \\
\hline \multirow{3}{*}{ D } & 1次 & 0.12 & $\frac{000}{1250}$ & 0.40 \\
\hline & 2次 & 0.224 & 811 & 0.26 \\
\hline & 3次 & 0.115 & 12 & 0.00 \\
\hline
\end{tabular}

表 3 柱断面詳細

表 4 梁断面詳細

\begin{tabular}{|c|c|c|c|c|c|c|c|c|}
\hline \multirow{2}{*}{ 階 } & \multirow{2}{*}{$\begin{array}{c}\mathrm{Fc} \\
{\left[\mathrm{N} / \mathrm{mm}^{2}\right]}\end{array}$} & \multirow{2}{*}{\begin{tabular}{|c|} 
断面 [mm] \\
$\mathrm{B} \times \mathrm{D}$ \\
\end{tabular}} & \multicolumn{3}{|c|}{ 主筋 } & \multicolumn{3}{|c|}{ せん断補強筋 } \\
\hline & & & 種別 & $x$ 方向 & $y$ 方向 & 種別 & x方向 & $y$ 方向 \\
\hline $12 \sim 9$ & 27 & $900 \times 800$ & $\frac{D 34}{D 20}$ & 5-D29 & $\frac{2}{2-015}$ & SD295 & 2-D13@100 & 2-D13@100 \\
\hline $8 \sim 7$ & 30 & $900 \times 800$ & $\begin{array}{l}\text { SD345 } \\
\end{array}$ & 5-D29 & \begin{tabular}{|l|l|}
$2-\mathrm{D} 29$ \\
$3-01$
\end{tabular} & SD295 & 2-D13@100 & 2-D13@100 \\
\hline $6 \sim 5$ & 30 & $900 \times 900$ & \begin{tabular}{|l} 
SD345 \\
SD295
\end{tabular} & 9-D29 & \begin{tabular}{|l|} 
2-D29 \\
3-D16
\end{tabular} & 295 & 00 & 100 \\
\hline $4 \sim 1$ & 36 & $\times 900$ & $\begin{array}{l}\text { SD345 } \\
\text { SD295 }\end{array}$ & 9-D29 & \begin{tabular}{|l|} 
2-D29 \\
3-D16
\end{tabular} & SD295 & 2-D13@100 & 2-D13@100 \\
\hline
\end{tabular}

表 5 壁断面詳細

\begin{tabular}{|c|c|c|c|c|}
\hline \multirow{2}{*}{ 嘴 } & \multirow[t]{2}{*}{ 壁厚 } & \multirow{2}{*}{$\frac{\mathrm{Fc}^{\mathrm{r} / \mathrm{mm}^{2}}}{\mathrm{In}}$} & \multicolumn{2}{|r|}{ 壁筋 } \\
\hline & & & 福别 & $\begin{array}{l}\text { 維能能 } \\
\end{array}$ \\
\hline $2 \sim 9$ & 150 & 27 & \begin{tabular}{|l|} 
SD295 \\
\end{tabular} & 1-D10@150 \\
\hline$\sim 7$ & 150 & 30 & \begin{tabular}{|l|} 
SD2295 \\
\end{tabular} & 1-D10@150 \\
\hline & 180 & & $\begin{array}{l}\text { SD295 } \\
\end{array}$ & 2-D10@200 \\
\hline$+\sim$ & 180 & 36 & \begin{tabular}{|l|l|} 
SD295 \\
\end{tabular} & 2-D10@20 \\
\hline
\end{tabular}

ースシア係数はそれぞれ $0.86 、 0.84 、 0.84$ および 0.94 である。

解析は市販の解析ソフト「SNAP Ver.4.0」9)を用いて、モード適応 型静的非線形荷重増分解析 ${ }^{1)}$, 10) (以下、MAP 解析と呼称) と時刻歴 地震応答解析を行った。時刻歴地震応答解析における入力地震波は El Centro NS（1940）の最大速度を $100 \mathrm{~cm} / \mathrm{sec} に$ 基準化したものを用 い、入力時間は地震動の主要な 10 秒間とした。数值積分には Newmark- $\beta$ 法 $(\beta=1 / 4)$ を用い、積分時間刻みを 0.001 秒とした。

\begin{tabular}{|c|c|c|c|c|c|c|c|c|c|}
\hline \multirow{2}{*}{ 符号 } & \multirow{2}{*}{ 階 } & \multirow{2}{*}{$\frac{\mathrm{Fc}}{\left[\mathrm{N} / \mathrm{mm}^{2}\right]}$} & \multirow{2}{*}{$\begin{array}{c}\text { 断面 [mm] } \\
\mathrm{B} \times \mathrm{D} \\
\end{array}$} & \multicolumn{4}{|c|}{ 主筋 } & \multicolumn{2}{|c|}{ せん断補強筋 } \\
\hline & & & & 種別 & $\searrow$ & 一段筋 & 二段筋 & 種別 & スターラップ \\
\hline \multirow{5}{*}{ GA } & $\mathrm{R} \sim 9$ & 27 & $500 \times 800$ & SD345 & $\begin{array}{ll}\text { 上 } \\
\text { 下 }\end{array}$ & $\begin{array}{l}5-\mathrm{D} 29 \\
5-\mathrm{D} 29\end{array}$ & $\begin{array}{l}3-\mathrm{D} 29 \\
2-\mathrm{D} 29\end{array}$ & SD295 & 3-D13@100 \\
\hline & 8 & 30 & $500 \times 800$ & SD345 & 上卡 & $\begin{array}{l}5-\mathrm{D} 29 \\
5-\mathrm{D} 29 \\
\end{array}$ & $\begin{array}{l}3-\mathrm{D} 29 \\
2-\mathrm{D} 29 \\
\end{array}$ & SD295 & 3-D13@100 \\
\hline & $7 \sim 5$ & 30 & $550 \times 850$ & SD345 & 上下 & $\begin{array}{l}6-\mathrm{D} 29 \\
6-\mathrm{D} 29\end{array}$ & $\begin{array}{l}\text { 4-D29 } \\
3-D 29\end{array}$ & SD295 & 3-D13@100 \\
\hline & $4 \sim 2$ & 36 & $550 \times 850$ & SD345 & 上卡 & $\begin{array}{l}6-\mathrm{D} 29 \\
6-\mathrm{D} 29 \\
\end{array}$ & $\begin{array}{l}4-\mathrm{D} 29 \\
3-\mathrm{D} 29 \\
\end{array}$ & SD295 & 3-D13@100 \\
\hline & 1 & 36 & $600 \times 2500$ & SD345 & 上下 & $\begin{array}{l}6-D 355 \\
6-D 35\end{array}$ & $\begin{array}{l}6-\mathrm{D} 35 \\
6-\mathrm{D} 35 \\
\end{array}$ & SD295 & 3-D13@100 \\
\hline \multirow{4}{*}{ GB } & $\mathrm{R} \sim 9$ & 27 & $350 \times 650$ & SD345 & 上卡 & $\begin{array}{l}3-\mathrm{D} 29 \\
3-\mathrm{D} 29\end{array}$ & & SD295 & 3-D13@100 \\
\hline & $8 \sim 5$ & 30 & $350 \times 650$ & SD345 & $\begin{array}{ll}\text { 上 } \\
\text { 下 }\end{array}$ & $\begin{array}{l}3-\mathrm{D} 29 \\
3-\mathrm{D} 29\end{array}$ & & SD295 & 3-D13@100 \\
\hline & $4 \sim 2$ & 36 & $350 \times 650$ & SD345 & 上卡 & $\begin{array}{l}3-\mathrm{D} 29 \\
3-\mathrm{D} 29\end{array}$ & & SD295 & 3-D13@100 \\
\hline & 1 & 36 & $600 \times 2500$ & SD345 & $\begin{array}{ll}\text { 上 } \\
\text { 下 }\end{array}$ & $\begin{array}{l}6-\mathrm{D} 35 \\
6-\mathrm{D} 35\end{array}$ & $\begin{array}{l}6-\text { D35 } \\
6-\text { D35 }\end{array}$ & SD295 & 3-D13@100 \\
\hline
\end{tabular}

粘性減衰は瞬間剛性比例型とし、弾性 1 次固有周期に対して減衰定 数を $5 \%$ とし、床には積載荷重として $10 \mathrm{kN} / \mathrm{m}^{2}$ を作用させた。なお、 地震波の入力方向は、㧖れ振動が卓越する $x$ 方向のみとした。

各解析モデルは、柱をマルチスプリングモデル（MS モデル）と し、梁には復元力特性をTakeda モデルとした材端バネモデルを用い た。また、耐震壁は TVLE モデル（壁谷澤モデル）を用い、曲げバ ネには Takeda モデルを、せん断バネには原点指向型トリリニアモデ 
ルを復元力特性として与えた。なお、各モデルは $x$ 方向に比べて $y$ 方向の層剛性が低いため、実際の 1 次モードは $y$ 方向へ並進するモ ードとなる。しかし、据れを伴う振動は $x$ 方向へ載荷することによ って生じるため、本研究の MAP 解析および時刻歴地震応答解析で は $y$ 方向へ並進するモードは除外している。

\section{3. セットバック建築物の重心位置における層間変位の取扱い}

一般的に層間変位は上下層の重心位置における相対水平変位から 求めているが、据れを伴うセットバック建築物では、セットバック している $j$ 層とセットバックしていない $j-1$ 層で重心位置が同一 鉛直線上に重ならない。そのため、図 3 に示すように、 $j$ 層の層間 変位 ${ }_{s t} \delta_{x j}$ は $j$ 層と $j-1$ 層の重心位置による相対変位の差 $\left(={ }_{s t} \delta_{x j}^{\prime}\right)$ ではなく、 $j$ 層の重心位置における基礎からの相対変位 $\delta_{x j}$ と当該 重心位置直下の $j-1$ 層の基礎からの相対変位 $\delta_{x j-1}^{\prime}$ を用いて式(1) により与えられる。

$$
{ }_{s t} \delta_{x j}=\delta_{x j}-\delta_{x j-1}^{\prime}
$$

ここで、相対変位 $\delta_{x j-1}^{\prime}$ は $j-1$ 層の重心位置 $G_{y j-1}$ における相対変位 $\delta_{x j-1}$ に当該層の重心まわり回転角 $\theta_{j-1}$ と $j$ 層の重心位置 $G_{y j}$ を考慮 して式(2)によって与えられる。

$$
\delta_{x j-1}^{\prime}=\delta_{x j-1}-\left(G_{y j}-G_{y j-1}\right) \cdot \theta_{j-1}
$$

ちなみに、 $y$ 方向構面がセットバック寸る場合についても同様に、 セットバック層の層間変位 ${ }_{s t} \delta_{y j}$ およびセットバック直下層の相対 変位 $\delta_{y j-1}$ は式(3)および(4)よって得られる。

$$
\begin{aligned}
{ }_{s t} \delta_{y j} & =\delta_{y j}-\delta_{y j-1}^{\prime} \\
\delta_{y j-1}^{\prime} & =\delta_{y j-1}-\left(G_{x j}-G_{x j-1}\right) \cdot \theta_{j-1}
\end{aligned}
$$

また、 $j$ 層の重心まわり（ $z$ 軸まわり）の基礎からの相対回転変 位 $\delta_{z j}$ は $\theta_{j}$ と回転半径 $i_{j}$ を用いて式(5)で与えられる。

$$
\delta_{z j}=\theta_{j} \cdot i_{j}
$$

なお、後述の 5 章で述べる等価 1 自由度系への縮約の場合には、 層間変位ではなく、各層における重心位置の基礎に対する相対水平 変位を用いるので、上記のような考慮は必要ない。

\section{4. 時刻歴地震応答解析結果}

時刻歴地震応答解析結果から得られた全モデルの重心における $x$ 方向の層間変位 ${ }_{s t} \delta_{x j}$ と各層における重心まわりの回転変位増分 ${ }_{s t} \delta_{z j}$ の最大応答分布を図 4 に示す。図中の○および $\triangle$ 印はそれぞれ ${ }_{s t} \delta_{x j}$ および ${ }_{s t} \delta_{z j}$ を示し、点線はセットバック層を表している。なお、 回転変位増分 ${ }_{s t} \delta_{z j}$ は次式により求めた。

$$
{ }_{s t} \delta_{z j}=\delta_{z j}-\delta_{z j-1}
$$

$x$ 方向の層間変位 ${ }_{s t} \delta_{x j}$ は上層ほど大きくなり、特にセットバック 層において増大していることが見てとれる。この傾向は下層側にセ ットバック層があるモデル C および D で顕著に認められる。変位の 大きさについて比較すると、同様のセットバック形状を有するモデ ル $\mathrm{A}$ および $\mathrm{C}$ では最上層での層間変位は $2 \mathrm{~cm}$ 程度となっている。 それに対して、セットバック層の最も多いモデル D では最上層の層 間変位は約 $1.6 \mathrm{~cm}$ 程度であり、並進方向への変位がほかのモデルに 比べて小さくなっている。また、モデル C とモデル D において共通 のセットバック層である 7 層での変位を比較すると、モデル C はモ デル D より 2 倍近く大きくなっている。

重心まわりの回転変位増分 ${ }_{s t} \delta_{z j}$ はセットバック層が最上層にあ るモデル A やモデル $\mathrm{B}$ よりもセットバック層が下層側にあるモデル
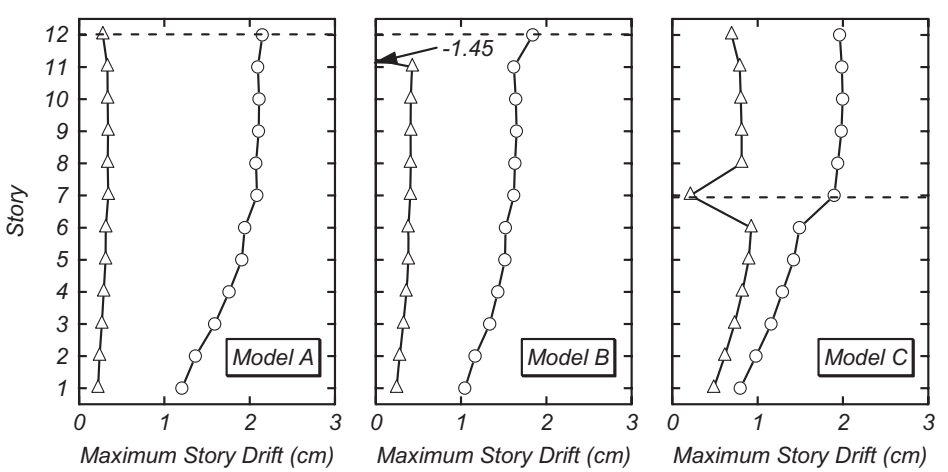

Maximum Story Drift $(\mathrm{cm})$

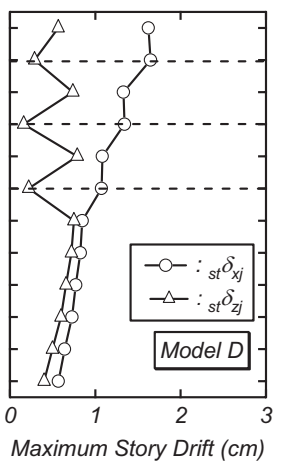

図 4 各モデルにおける層間変位の最大值分布
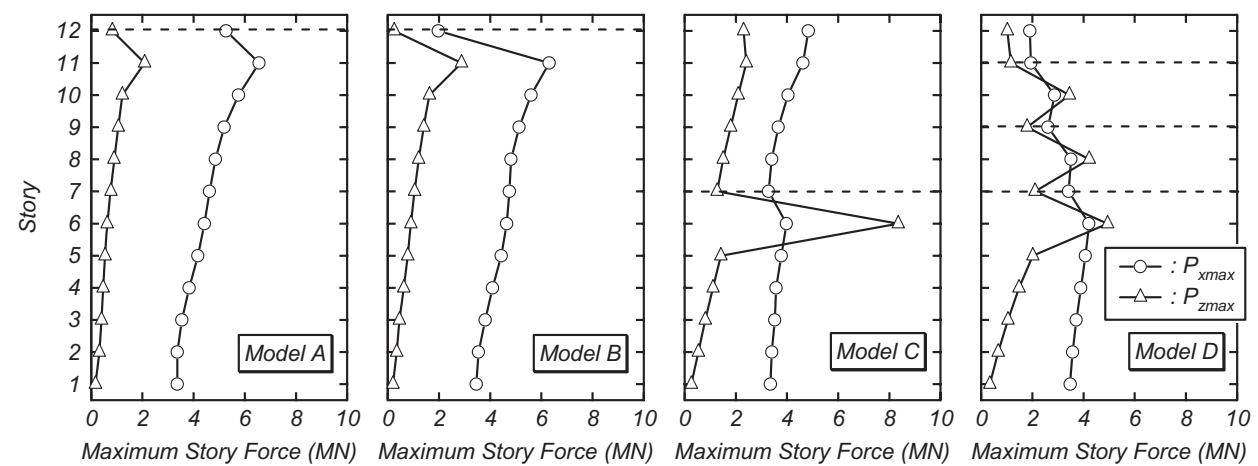

図 6

各モデルにおける層外力の最大值分布

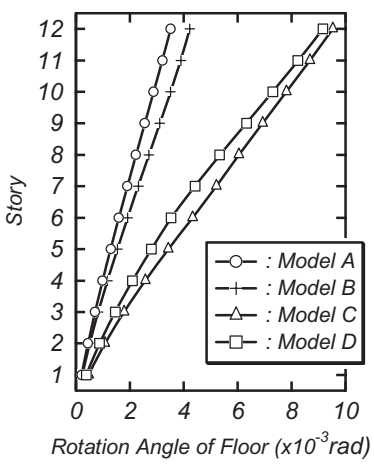

図 5 回転角の最大值分布 
$\mathrm{C}$ やモデル D のほうが全体的に大きくなる傾向がある。また、モデ ル C の 7 層およびモデル D の 7、9および 11 層に見られるように、 セットバック層では ${ }_{s t} \delta_{z j}$ が小さくなる傾向も認められる。

ところで、重心まわりの回転変位 $\delta_{z j}$ は式(5)からも明らかなよう に、重心まわりの回転角 $\theta_{j}$ と回転半径 $i_{j}$ によって与えられる。そこ で、上記の ${ }_{s t} \delta_{z j}$ の最大応答分布の傾向の原因を検討寸るために、各 モデルにおける $\theta_{j}$ の最大応答分布を調べた結果を図 5 に示す。同図 より、全層にわたる $\theta_{j}$ の増加割合はモデル毎にほぼ一定であり、セ ットバック層による回転角の変化は顕著には認められない。したが って、セットバック層において ${ }_{s t} \delta_{z j}$ が小さくなる原因は、表 1 に示 したセットバック層での回転半径 $i_{j}$ が基準層のものに比して小さ くなっているためであるといえよう。また、 $\theta_{j}$ の増加割合はセット

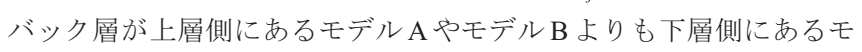
デル $\mathrm{C}$ および D のほうがかなり大きくなっており、回転変位増分 ${ }_{s t} \delta_{z j}$ の傾向と一致している。

図 6 は各層の重心位置に作用する外力の $x$ 方向成分 $P_{x j}$ および $z$ 軸まわりの成分 $P_{z j}$ （重心まわりのモーメント $M_{z j}$ を回転半径 $i_{j}$ で 除したせん断力から求めたもの)の最大值分布 $\left(P_{x \max }\right.$ および $\left.P_{z \max }\right)$ を示している。

同図より、セットバック層の直下層に作用する外力が $x$ 方向およ び $z$ 軸まわりの両方で卓越していることが認められる。最上層でセ

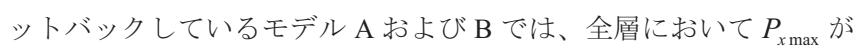
$P_{z \max }$ に比して大きく、かつ、両外力ともにセットバック直下層に おいて最大となっている。

一方、下層側でセットバックしているモデルに関して、7 層のみ
がセットバックしているモデル $\mathrm{C}$ では $P_{x \max }$ および $P_{z \max }$ がともに セットバック層で減少寸るものの、上層になるにつれて両外力が 徐々に増加している。それに対して、複数層にセットバック層があ るモデル D では、各セットバック層において $P_{x \max }$ および $P_{z \max }$ とも に減少し、かつ、上層になるほど外力は小さくなる傾向が認められ る。また、 $P_{z \max }$ はセットバック直下層で急増するが、基準層では 比較的小さな值となっている。これはセットバック層とその直下層 で重心位置が異なるため、セットバック層直下における㧖れモーメ ントが急増したためであると推察される。さらに、モデルC とモデ ル D とで共通のセットバック直下層（6層）における $P_{z \max }$ を比較 すると、モデル C のほうがモデル D に比して 2 倍近く大きくなって いる。これはモデル D のセットバック構面が多いため、上層の質量 が小さくなり据れ応答が小さくなったためであると考えられる。

図 7 は $x$ 方向各構面の最大層間変位分布を示したものである。各 モデル共に、Y1 構面から Y 5 構面に向かうほど層間変位が大きくな り、高い構面側がより大きく振られる傾向が見てとれる。また、図 4 との比較から明らかなように、各層における重心まわりの回転変 位増分 ${ }_{s t} \delta_{z j}$ の最大応答值が比較的小さかったモデル A および B で は、モデル C および D に比べて各構面の最大層間変位の差が小さく なっており、据れ応答が小さいことが認められる。すなわち、 ${ }_{s t} \delta_{z j}$ の大きさが各構面の最大層間変位に大きく影響を及ぼしているとい える。なお、モデル D では $\mathrm{Y} 1$ 構面の最大層間変位が $\mathrm{Y} 2$ 構面のも のに比して大きくなっており、他の構面、あるいは他のモデルと異 なる傾向を示しているが、これは図 7 が最大層間変位の絶対值で表 示しているためであり、実際にはY1構面の值は負値となっている。
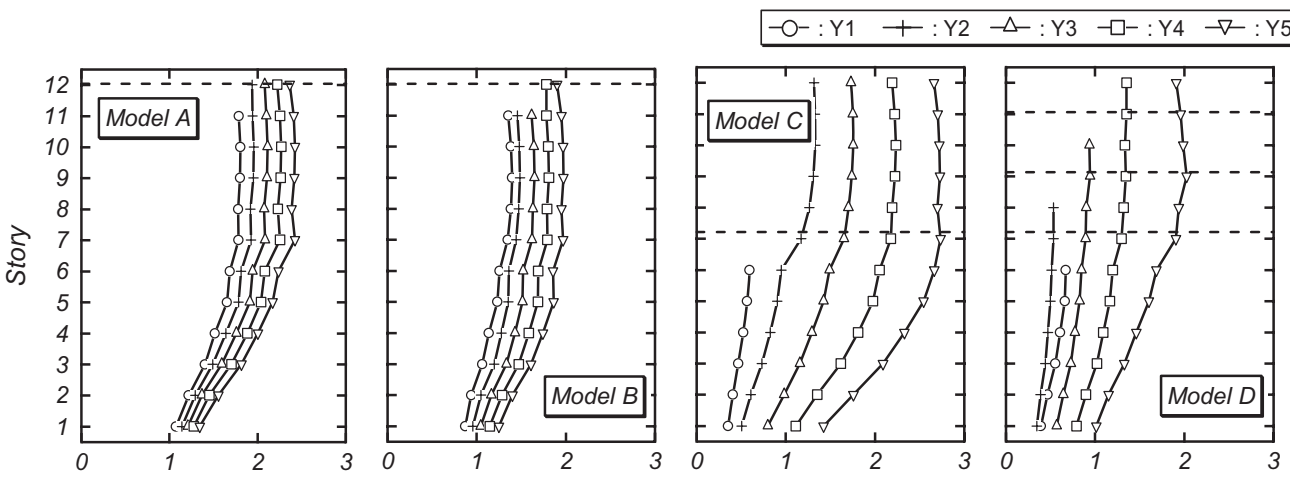

Frame Displacement (cm) Frame Displacemnt (cm) Frame Displacement (cm) Frame Displacement (cm)

図 7 各モデルにおける構面層間変位の最大值分布
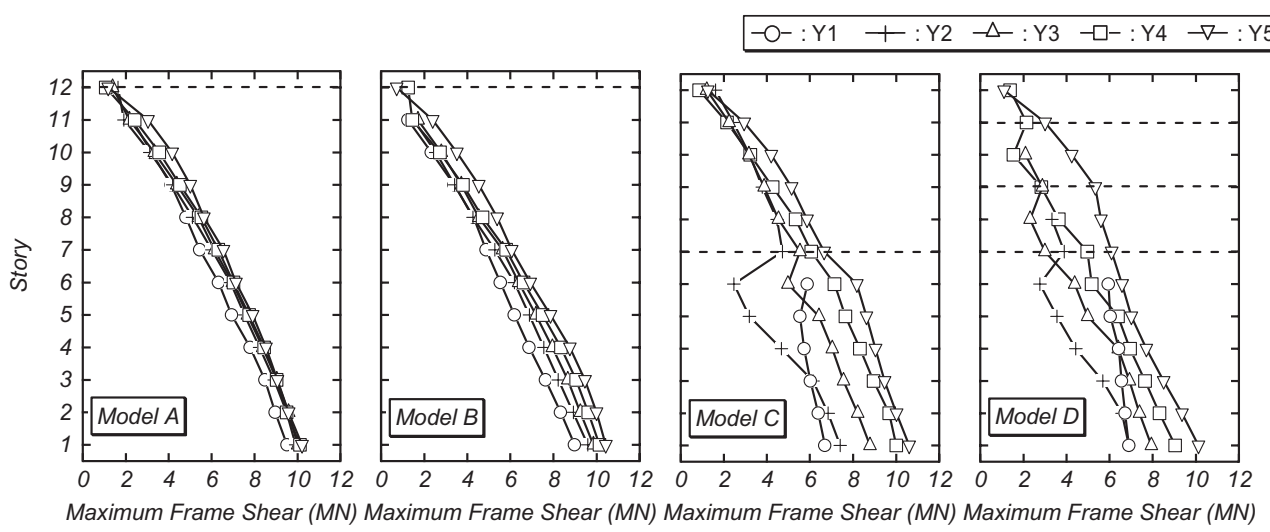

図 8

各モデルにおける構面せん断力の最大值分布 

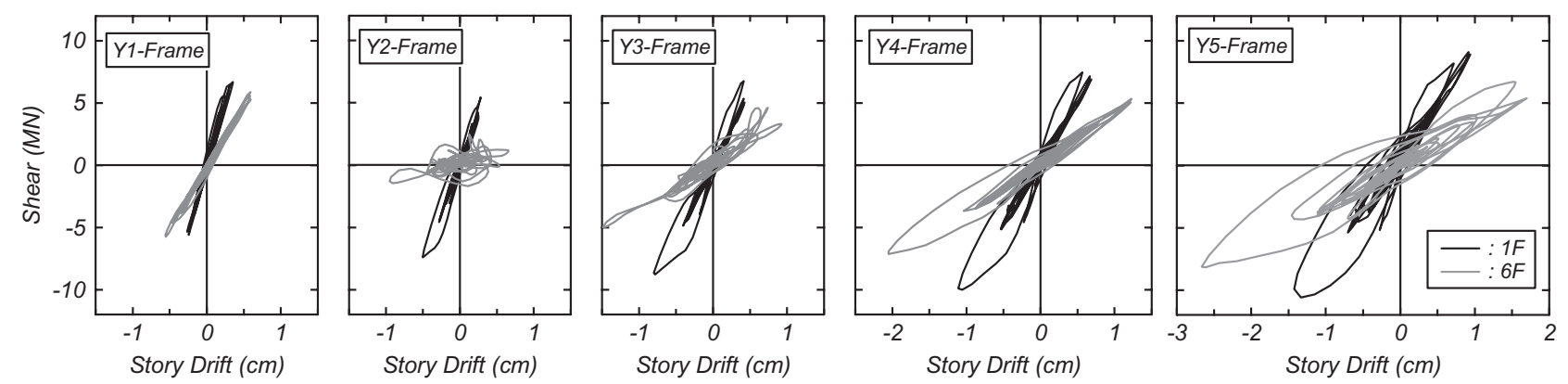

図 9 モデル C の 1 層およびセットバック直下層（6 層）

における各構面の層せん断力一層間変位関係

図 8 は $x$ 方向各構面の最大応答せん断力分布を示したものである。 同図より、各モデルともに最上層を除き、最大応答せん断力は高層 側の構面である Y5 構面において最も大きく、低層側の構面となる Y1 および Y2 構面が小さくなっている。セットバック構面が最上層 にあるモデル Aおよび $\mathrm{B}$ では構面毎の最大応答せん断力分布にあま り差は認められない。一方、セットバック層が下層側にあるモデル $\mathrm{C}$ および D では、共通のセットバック直下層（6 層）において Y2 構面のせん断力が上層に比べて大きく低下しているが、逆に Y1 構 面のせん断力が Y2 構面の 2 倍以上のせん断力を負担していること が見てとれる。さらに、それ以下の層における最大応答せん断力は、 $\mathrm{Y} 1$ 構面では 6 層とほぼ同じか若干大きくなる程度であるが、Y2 構 面では下層になるほど増加し、1 層では Y1 構面よりも大きくなって いる。この傾向は、モデル D における他のセットバック直下層にお いても確認できる。

建築物の地震応答性状に及ぼすセットバックの影響を検討するた めに、モデル C の 1 層と 6 層（セットバック直下層）の各構面にお ける層せん断力一層間変位関係を比較したものを図 9 に示す。

1 層および 6 層ともに Y 1 構面から Y 5 構面に向かって最大応答変 位が大きくなっており、高層側の構面（Y5 構面側）が振られる捩れ 応答が生じていることが確認できる。また、6 層では Y 2 および $\mathrm{Y} 3$ 構面といった中間構面において応答に乱れが生じているが、これら の構面では両端の構面よりも最大応答せん断力が小さいことがわか る。なお、 6 層における Y 1 構面の応答せん断力の位相は、他の構面 のものとは逆となっている。一方、1 層では Y2 および Y 3 構面にお いても応答の乱れは認められず、各構面ともに概数定常的な応答性 状を示している。これらのことから、セットバック建築物ではセッ トバック直下層における構面間のせん断力伝達が複雑であり、特に、 セットバック構面の隣接構面（Y2 構面）からセットバック構面（Y1 構面）へのせん断力伝達が大きいといえる。

\section{5. 等価 1 自由度系縮約}

セットバックのある建築物の等価 1 自由度系への静的縮約は、多 層偏心建築物の静的縮約 ${ }^{2)}$ と同様に、立体モデルによる MAP 解析 ${ }^{1)}$ の結果を用いて行うことができる。すなわち、等価 1 自由度系の代 表加速度 $S_{1} S_{a}$ および代表変位 ${ }_{1} S_{d}$ は式(7)および(8)で与えられる。

$$
\begin{aligned}
{ }_{1} S_{a} & =\frac{\left\{\left\{_{1} \delta\right\}^{T}\left\{{ }_{1} P\right\}\right.}{\left\{{ }_{1} \delta\right\}^{T}[M]\{1\}_{x}} \\
{ }_{1} S_{d} & =\frac{\left.\left.\left\{{ }_{1} \delta\right\}^{T}[M]\right\}_{1} \delta\right\}}{\left\{_{1} \delta\right\}^{T}[M]\{1\}_{x}}
\end{aligned}
$$
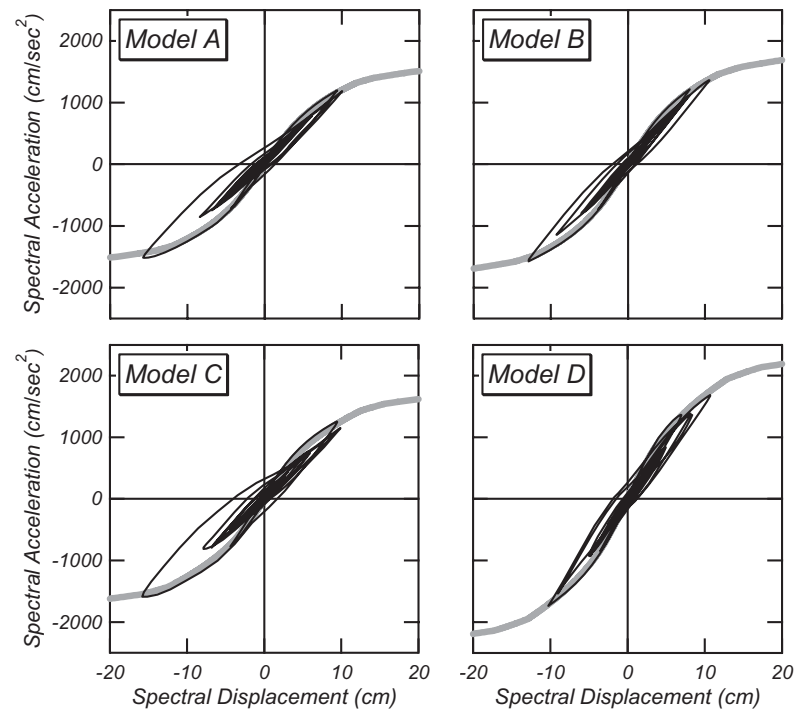

図 10 等価 1 自由度系の静的縮約結果と動的縮約結果の比較

$$
\begin{aligned}
\text { ここに、 } & {[M]: \text { 質量マトリクス } } \\
& \left\{{ }_{1} P\right\}: \text { 外力ベクトルの } 1 \text { 次モード成分 } \\
& \left\{{ }_{1} \delta\right\}: \text { 重心位置の変位ベクトルの } 1 \text { 次モード成分 } \\
& \{1\}_{x}: \text { 外力分布ベクトル }\left(=\left\{\{1\}^{T},\{0\}^{T},\{0\}^{T}\right\}^{T}\right)
\end{aligned}
$$

一方、動的縮約による等価 1 自由度系の代表加速度 ${ }_{1} S_{a}(t)$ および 代表変位 ${ }_{1} S_{d}(t)$ は、MAP 解析で用いたものと同じ立体モデルによる 時刻歴地震応答解析結果を用いて、それぞれ式(9)および(10)によっ て与えられる。その際、1 次の刺激関数 ${ }_{1} \beta\left\{{ }_{1} U\right\}$ は式(11)による ${ }^{2)}$ 。

$$
\begin{aligned}
& { }_{1} S_{a}(t)=\frac{{ }_{1} \beta\left\{{ }_{1} U\right\}^{T}\{P(t)\}}{{ }_{1} \bar{M}} \\
& { }_{1} S_{d}(t)=\frac{{ }_{1} \beta\left\{{ }_{1} U\right\}^{T}[M]\{\delta(t)\}}{{ }_{1} \bar{M}} \\
& { }_{1} \beta\left\{{ }_{1} U\right\}=\frac{\left\{{ }_{1} \delta_{\text {max }}\right\}^{T}[M][1\}_{x}}{\left\{{ }_{1} \delta_{\text {max }}\right\}^{T}[M]\left\{{ }_{1} \delta_{\text {max }}\right\}}\left\{{ }_{1} \delta_{\text {max }}\right\} \\
& \text { ここに、 }{ }_{1} \bar{M} \quad: 1 \text { 次の等価質量 } \\
& \{P(t)\} \text { : 外力ベクトル } \\
& \left\{{ }_{1} \delta(t)\right\}: \text { 重心位置の変位ベクトル } \\
& \left\{{ }_{1} \delta_{\max }\right\} \text { : MAP 解析において参照モードを採用したス } \\
& \text { テップの重心位置の変位ベクトル }
\end{aligned}
$$

図 10 に各解析モデルの等価 1 自由度系縮約結果を示す。図中の灰 色線は静的縮約結果を、黒色線は動的縮約結果をそれぞれ表す。 
各モデルともに、静的縮約結果と動的縮約による履歴曲線の包絡 線が良好な対応関係にあり、両縮約結果は妥当なものであるといえ る。また、同図からセットバック構面の多いモデル B や D はセット バック構面が 1 つのモデル A および C に比べて初期剛性が大きく、 結果として同一代表変位における代表加速度が大きくなる傾向が認 められる。これは、, $S_{a}={ }_{1} \omega^{2} \cdot{ }_{1} S_{d}\left({ }_{1} \omega=2 \pi /{ }_{1} T\right)$ の関係 ${ }^{11)}$ からもわ かるように、各モデルの 1 次固有周期 ${ }_{1} T$ (表 2 参照）の違いに依存 するものである。

\section{6. 構面の地震応答性状}

時刻歴地震応答解析で得られた各解析モデルにおける $x$ 方向構面 の応答結果を 1 次モード成分と高次モード成分に分解し、それぞれ の地震応答特性を検討寸る。なお、1 次モード成分は文献 3)に示す 方法により求めものとする。一方、高次モード成分については後述 するように（式(15)および(16)）、各構面の応答結果から 1 次モード 成分を差し引くことにより評価するものとする。

文献 3)によれば、多層偏心建築物における $x$ 方向 $j$ 層 $i$ 構面の応 答変位の 1 次モード成分 ${ }_{1} \delta_{x j, i}(t)$ は、等価 1 自由度系における並進モ ード成分 ${ }_{1} u_{x j}$ と回転モード成分 ${ }_{1} u_{z j}$ および重心から $i$ 構面までの距 離 $l_{y j, i}$ を用いて式(12)によって与えられる。

$$
{ }_{1} \delta_{x j, i}(t)={ }_{1} \beta\left({ }_{1} u_{x j}-\frac{l_{y j, i}}{i_{j}} \cdot{ }_{1} u_{z j}\right) \cdot{ }_{1} S_{d}(t)
$$

また、応答せん断力の 1 次モード成分 ${ }_{1} Q_{x j, i}(t)$ は

$$
{ }_{1} Q_{x j, i}(t)=\sum_{k=j}^{N} m_{k} \cdot{ }_{1} \beta \cdot{ }_{1} u_{x k, i} \cdot{ }_{1} S_{a}(t)
$$

で与えられる。ここで、 ${ }_{1} \beta \cdot{ }_{1} u_{x j, i}$ は $x$ 方向 $j$ 層 $i$ 構面に対する見か けの 1 次刺激関数 ${ }^{12)}$ であり、MAP 解析において参照モードを採用し たステップでの当該構面に作用する外力 ${ }_{1} P_{x j, i \max }$ と代表加速度 ${ }_{1} S_{a \max }$ を用いて式(14)から求められる。

$$
{ }_{1} \beta \cdot{ }_{1} u_{x j, i}=\frac{{ }_{1} P_{x j, i \max }}{m_{j} \cdot 1 S_{a \max }}
$$

一方、 $x$ 方向 $j$ 層 $i$ 構面の応答変位および応答せん断力の高次モ 一ド成分 ${ }_{h} \delta_{x j, i}(t)$ および ${ }_{h} Q_{x j, i}(t)$ は、下式に示すように、それぞれ時 刻歴応答解析結果 $\left(\delta_{x j, i}(t)\right.$ および $\left.Q_{x j, i}(t)\right)$ から上記の 1 次モード成 分を差し引くことによって求める。

$$
\begin{aligned}
& { }_{h} \delta_{x j, i}(t)=\delta_{x j, i}(t)-_{1} \delta_{x j, i}(t) \\
& { }_{h} Q_{x j, i}(t)=Q_{x j, i}(t){ }_{1} Q_{x j, i}(t)
\end{aligned}
$$

図 11 は各層の重心位置に作用寸る外力の最大值分布とその 1 次モ

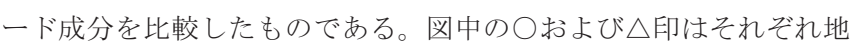
震応答解析結果から得られた $x$ 方向成分および $z$ 軸まわりの成分の 最大值 $P_{x \max }$ および $P_{z \max }$ を表しており、図 6 に示したものと同じも のである。また、のおよびム印がそれぞれの 1 次モード成分 ${ }_{1} P_{x \text { max }}$ お よび ${ }_{1} P_{z \max }$ に相当する。

各層の $x$ 方向に作用寸る外力に着目すると、セットバック層より 下層部では全外力の最大值 $P_{x \text { max }}$ がその 1 次モード成分 ${ }_{1} P_{x \max }$ に比 心゙てかなり大きく、かつ、その傾向は下層になるほど顕著であるが、 逆にセットバック層より上層では 1 次モード成分が支配的となって いることが見てとれる。すなわち、セットバック層を境に上層では 1 次モード成分が、下層では高次モード成分がそれぞれ卓越してい
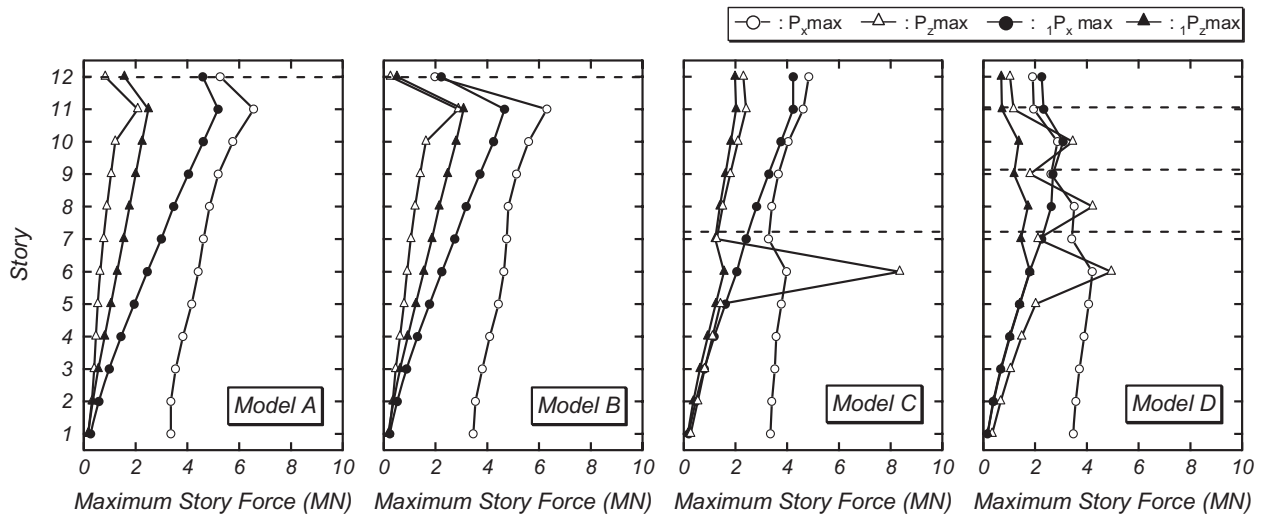

図 11 各層に作用する外力の最大值とその 1 次モード成分の比較
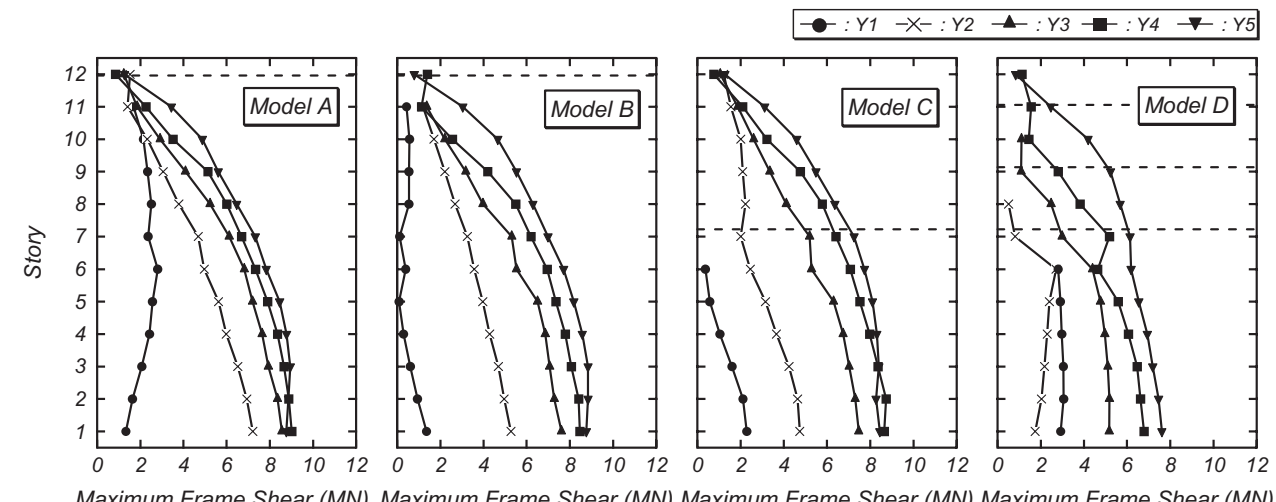

図 12 各層における構面せん断力の 1 次モード成分の分布 

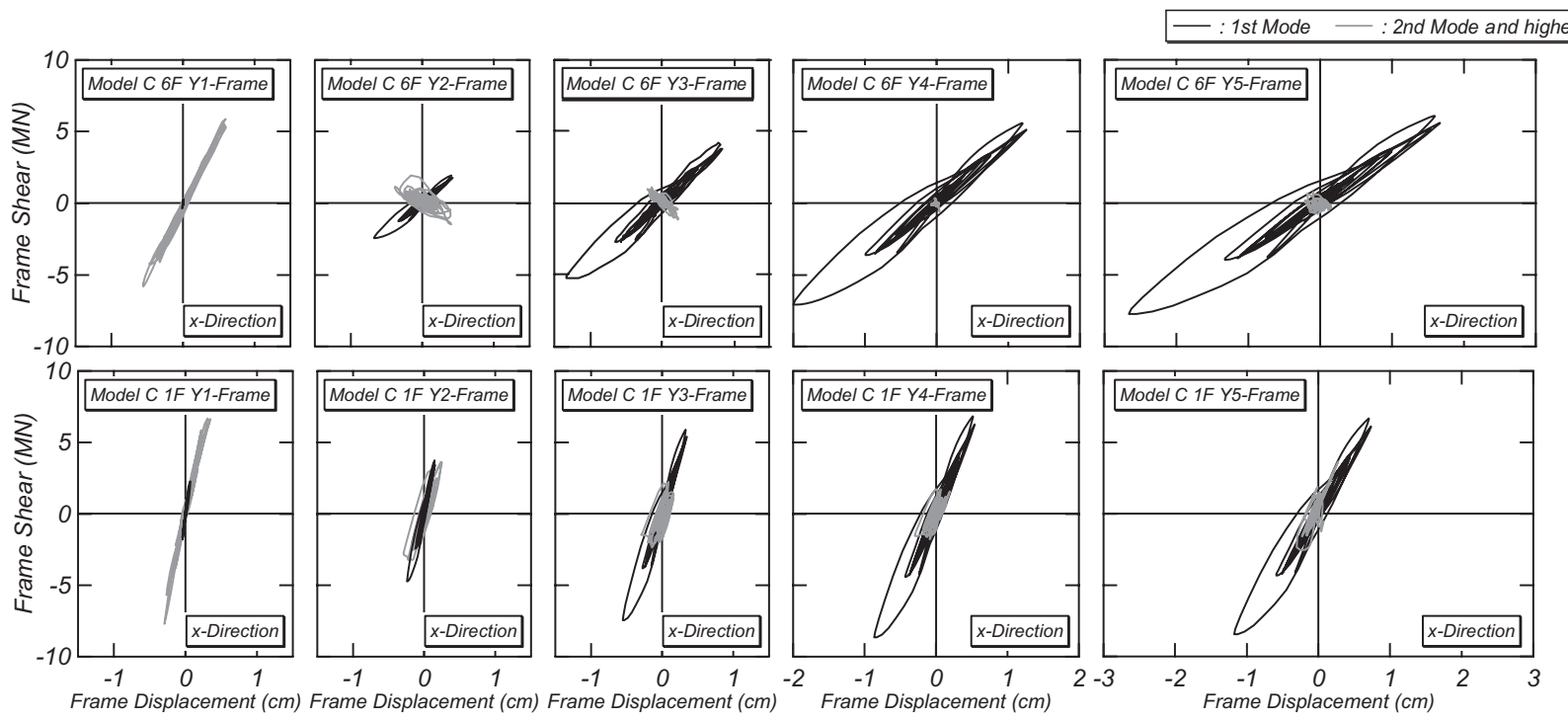

(a) モデル C（1 層および 6 層 $)$

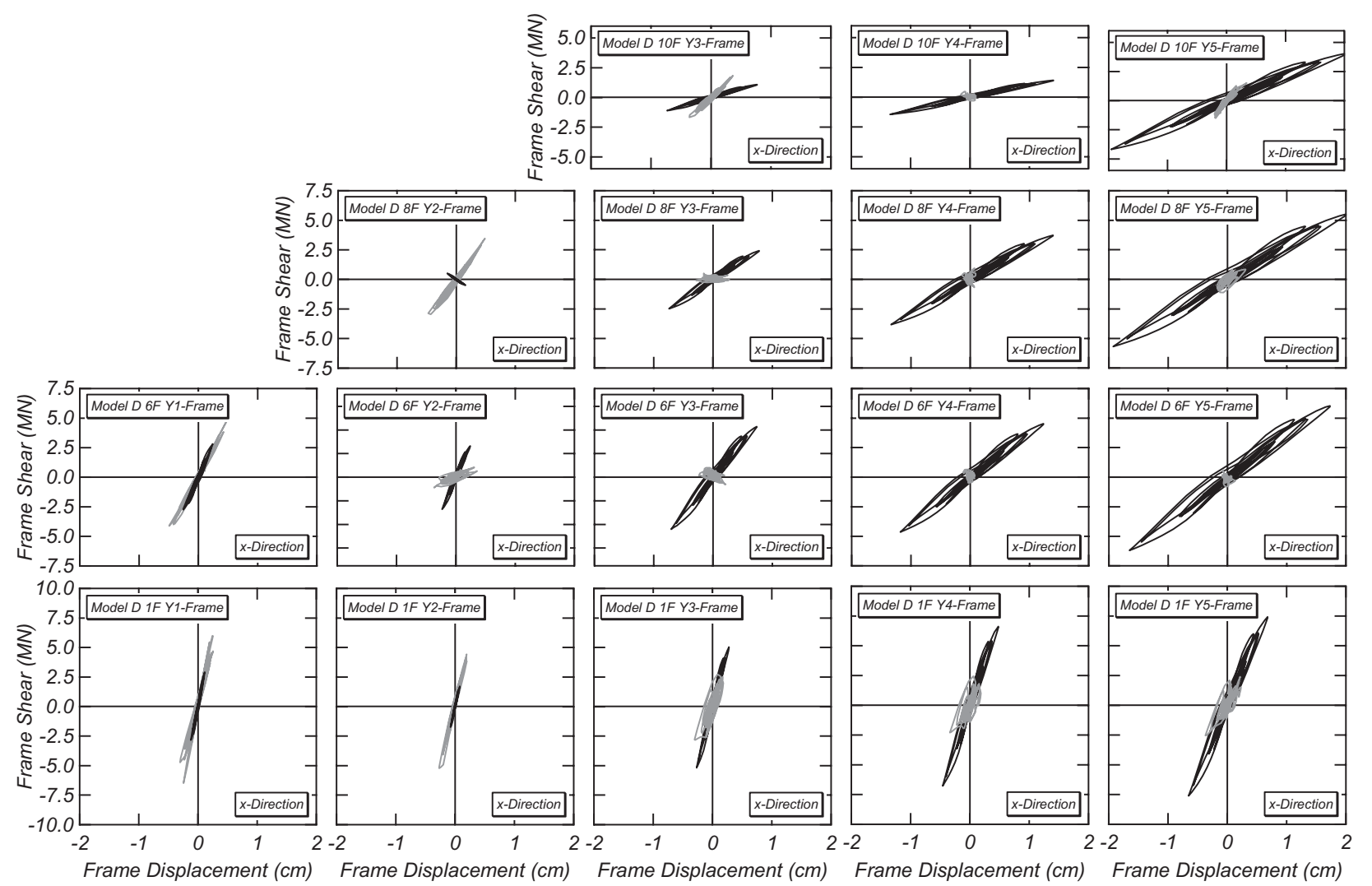

(b) モデル D （1 層、6 層、8 層および 10 層）

図 131 層およびセットバック直下層における各構面の層間応答の 1 次モード成分と高次モードの比較

ることが認められる。一方、4 章でも述べたように（図 6)、 $z$ 軸ま わりに作用寸る外力の最大值 $P_{z \max }$ はセットバック直下層で急増す る傾向があるが、1 次モード成分 ${ }_{1} P_{z \max }$ の分布はその傾向が極めて 少ない。すなわち、 $z$ 軸まわりに作用する外力はセットバック直下 層において高次モード成分が急増寸るが、その他の層では概ね 1 次 モード成分が卓越しているものと考えられる。

$x$ 方向各構面（Y1〜Y5 構面）に作用するせん断力の 1 次モード 成分の建築物高さ方向の分布を図 12 に示す。
各モデルともにY5 構面から Y1 構面に向かうにしたがって各層の せん断力が段階的に減少している。特に、セットバック構面が Y1 構面のみのモデル A〜C では、せん断力の減少傾向は下層ほど顕著 に認められ、かつ、Y1 構面と Y2 構面の減少度合いが極めて大きい。 これに対してセットバック構面が 3 構面あるモデル D では、Y2 構 面の負担せん断力が最も小さくなっており、Y5 構面から Y1 構面に かけての各層にけるせん断力の減少度合いは上層で大きく、セット バックのない6 層以下では小さくなっていることが見てとれる。各 
構面の最大せん断力分布を示した図 8 と比較すると、各モデルとも に下層になるほど、かつ、セットバック構面とその隣接構面におい て、最大せん断力とその 1 次モード成分との差が大きくなっており、 高次モード成分が卓越しているものと考えられる。

図 13(a)および(b)にモデル C およびモデル D の 1 層およびセット バック直下層での各構面の層せん断力－層間変位関係における 1 次 モード成分と高次モード成分を示す。図中の黒色線および灰色線は それぞれ 1 次モード成分および高次モード成分を表している。

図 13(a)より、モデル C では 1 層およびセットバック直下層 (6 層) ともに Y 5 構面から Y 1 構面にかけて段階的に 1 次モード成分が減少 し、逆に高次モード成分が増加する傾向が認められる。特に、セッ トバック直下層では 1 次モード成分はほとんど認められず、高次モ 一ド成分による定常的な振動が卓越していることがわかる。また、 セットバック直下層の Y 2 および Y 3 構面では、高次モード成分が 1 次モード成分に対して位相が概ね $90^{\circ}$ ずれた応答を呈しており、応 答自体も乱れたものとなっている。この結果は、図 9 に示した各構 面の層せん断力一層間変位関係において Y2およびY3 構面の応答に 乱れが生じていることと対応している (同図中の灰色線)。さらに、 1 層の $\mathrm{Y} 1$ 構面の応答に着目すると、全体応答は 1 次モード成分と高 次モード成分が累加されたものであるにもかかわらず、図 9 におけ る全体応答の最大せん断力（同図中の黒色線）は、図13(a)における 高次モード成分の最大せん断力（同図中の灰色線）よりも小さくな っていることが見てとれる。これは、Y1 構面では 1 次モード成分の 位相が逆転し、高次モード成分に対しても位相が概补 $180^{\circ}$ ずれた 応答となっているためである。

一方、図 13(b)に示寸モデル D においてもモデル C と同様に、1 層およびセットバック直下層（6、8 および 10 層）ともに Y 5 構面か ら Y2 構面にかけては、段階的に 1 次モード成分が減少し、高次モ 一ド成分が増加していくという傾向が見てとれる。しかし、Y1構面 に関しては、1 次モード成分が Y 2 構面のものに比べて大きくなる傾 向があり、セットバック数や形状の違いによる影響が若干認められ る。なお、この Y1 構面と $\mathrm{Y} 2$ 構面の 1 次モード成分の逆転現象も Y1 構面の位相が Y 2 構面のものに対して約 $180^{\circ}$ ずれたことに起因 している。

\section{7. まとめ}

本論では、セットバック建築物の地震応答特性の把握を目的とし て、セットバック形状の異なる 4 タイプの建築物について時刻歴地 震応答解析と MAP 解析を実施し、それらの結果に基づいて縮約さ れた等価 1 自由度系から 1 次モード応答特性を考察するとともに、 建築物全体および各構面の地震応答性状に及ぼす高次モード応答の 影響を検討した。

本研究で得られた知見を以下に要約する。

(1) セットバック建築物では一般的に各層の重心位置が同一鉛直線 上にないため、セットバック層の層間変位を求める場合にはセッ トバック層とセットバック直下層との重心位置のずれを考慮す る必要がある。その算定式は式(1)および(3)で与えられる。

(2) セットバック建築物では、セットバック層が上層部にある場合に は並進応答が据れ応答に比して卓越寸るが、セットバック層が下 層部になるほど捩れ応答が卓越する傾向にある。
(3) セットバック建築物では、セットバック直下層において㧖れ振動 が卓越する傾向にある。一方、セットバック層では㧖れ成分に比 べて並進成分が卓越するため、層間変形が増大寸る傾向がある。

(4) セットバック建築物に対しても多層偏心建築物と同様に、式(7) と(8)および式(9)と(10)によって等価 1 自由度系への静的縮約お よび動的縮約が可能である。

(5) セットバック建築物において地震動入力方向（ $x$ 方向）に作用す る外力あるいは層せん断力は、セットバック層より上層では 1 次モード成分が、下層では高次モード成分がそれぞれ卓越する傾 向にある。一方、 $z$ 軸まわりに作用する外力に関しては、セット バック直下層において高次モード成分が卓越するが、その他の層 では 1 次モード成分が支配的となる傾向がある。

(6) セットバック建築物の各構面の層せん断力ー層間変位応答にお いては、セットバックしている低層側構面からセットバックのな い高層側構面に向かうにしたがって 1 次モード成分が支配的と なり、高次モード成分が小さくなる傾向がある。

なお、上記の結論は、 $x$ 方向が 1 スパンの連層耐震壁構造で $y$ 方 向が純ラーメン構造で構成される典型的な集合住宅形式のセットバ ック建築物を対象として、 $x$ 方向のみに地震動を入力した解析から 得られたものであり、限られた検討範囲によるものである。したが って、より一般的なセットバック建築物の地震応答特性を把握する ためには、連層耐震壁とラーメン架構が混在するセットバック建築 物や斜め方向入力を受けるセットバック建築物等に対する検討も必 要である。今後の研究課題としたい。

\section{参考文献}

1) 倉本洋, 三浦直之, 星龍典：単層偏心建築物における等価 1 自由度系の 地震応答特性と高次モード応答の予測, 日本建築学会構造系論文集, 第 606 号, pp.123-130, 2006.8

2) 星龍典, 倉本洋 : 多層偏心建築物における等価 1 自由度系の地震応答特 性と高次モード応答の予測, 日本建築学会構造系論文集, 第 616 号, pp.89-96, 2007.6

3) 倉本洋, 星龍典 : 多層偏心建築物における各構面の地震応答評価, 日本 建築学会構造系論文集, 第 624 号, pp.251-257, 2008.2

4) 志賀敏男: セットバックのある建物の㧖れ振動, 日本建築學會研究報告, pp.300-303, 1961

5) 志賀敏男, 柴田明徳, 佐武直紀 : セットバック建物の弾塑性ねじれ地震 応答解析, 日本建築学会大会学術講演梗概集, B 分冊, pp.725-726, 1986.8

6) 柴田明徳, 佐武直紀 : セットバック型試設計建物の弾塑性ねじれ地震応 答解析 一高層壁式ラーメン構造に関する研究一, 日本建築学会大会学術 講演梗概集, C 分冊, pp.267-268, 1987.10

7) 佐武直紀：不整形状を有する建物のねじれに対する保有耐力の適性配分 に関する検討, 日本建築学会構造系論文報告集, No.445, pp.45-54, 1993.3 8) 福澤栄治, 岡野昌明, 奥津一雄 : 不整形平面をもつ高層立体架構の剛心 と剛性の主軸 (その 1 2), 日本建築学会大会学術講演梗概集, pp.801-804, 1984.10

9) 株式会社構造システム：SNAPVer.4.0 導入マニュアル

10) 倉本洋：多層建築物における等価 1 自由度系の地震応答特性と高次モー ド応答の予測，日本建築学会構造系論文集，第 580 号，pp.61-68，2004.6

11) 倉本洋, 勅使川原正臣, 小鹿紀英, 五十田博 : 多層建築物の等価 1 自由 度系縮約法と地震応答予測制度, 日本建築学会構造系論文集, 第 546 号, pp.79-85, 2001.8

12) 倉本洋, 秋田知芳: 多層壁フレーム建築物の等価 1 自由度系縮約と高次 モード応答せん断力の評価, 日本建築学会構造系論文集, 第 605 号, pp.79-86, 2006.7 